\title{
Sugarcane Vinasse, a Residue of Ethanol Industry: Toxic, Cytotoxic and Genotoxic Potential Using the Allium cepa Test
}

\author{
Janaína Pedro-Escher ${ }^{1}$, Cintya A. Christofoletti², Yadira Ansoar-Rodríguez ${ }^{1,3^{*}}$, \\ Carmem S. Fontanetti ${ }^{1}$ \\ ${ }^{1}$ UNESP-São Paulo State University, Rio Claro, Brazil \\ ${ }^{2}$ UNIARARAS-Hermínio Ometto Foundation, Araras, Brazil \\ ${ }^{3}$ Department of Pharmacology and Toxicology, Pharmacy and Food Institute, University of Havana, Havana, \\ Cuba \\ Email: *yansoar@gmail.com
}

Received 2 March 2016; accepted 4 April 2016; published 7 April 2016

Copyright (C) 2016 by authors and Scientific Research Publishing Inc.

This work is licensed under the Creative Commons Attribution International License (CC BY).

http://creativecommons.org/licenses/by/4.0/

(c) (i) Open Access

\section{Abstract}

The search for fuels to replace petroleum consumption has caused an increase in the production of biofuels worldwide. The ethanol, which comes from sugarcane, is an energy resource with low polluting potential, but its production generates other environmental problems. On average, 10 to 15 liters of vinasse are generated while preparing each liter of ethanol. Vinasse is the final by-product of the biomass distillation, mainly for the production of ethanol, from different cultures such as sugarcane. Because excessive quantities of vinasse are produced, alternatives have been required for use, for example as fertilizer, in a process known as fertigation. These excessive amounts of vinasse applied in soils have generated adverse effects on soil properties and to the organisms. This study carried out the toxic, cytotoxic and genotoxic potential of sugarcane vinasse obtained from two different harvests (Samples I and II), using the Allium cepa organism test. $A$. cepa seeds were exposed to raw vinasse (RV) and diluted in different concentrations: control soil + raw vinasse (SV); vinasse diluted in water at $50 \%$ + control soil (V $50 \%)$; vinasse diluted in water at $25 \%+$ control soil ( $\mathrm{V} 25 \%$ ); vinasse diluted in water at $12.5 \%+$ control soil (V $12.5 \%)$. The chemical characterization of vinasse samples showed a low $\mathrm{pH}$ and high concentration of potassium. The results demonstrate that the two RV samples tested are toxic, since no seeds germination was observed. The cytotoxic potential was observed in the sample II of SV and V (50\%). All groups evaluated in samples I and II, induced chromosomal alterations, statistically significant compared with negative control. An increase in frequency of micronuclei in meristematic cells was observed in the SV (Sample I) and all groups evaluated in samples II. Based on the results it is concluded that the genetic material of the test-system was damaged when exposed to sugarcane vinasse,

\footnotetext{
${ }^{*}$ Corresponding author.
}

How to cite this paper: Pedro-Escher, J., Christofoletti, C.A., Ansoar-Rodríguez, Y. and Fontanetti, C.S. (2016) Sugarcane Vinasse, a Residue of Ethanol Industry: Toxic, Cytotoxic and Genotoxic Potential Using the Allium cepa Test. Journal of Environmental Protection, 7, 602-612. http://dx.doi.org/10.4236/jep.2016.75054 
suggesting that one should be very careful in the use of this waste that has been used sometimes indiscriminately in soils.

\author{
Keywords
}

Micronucleus, Chromosome Aberrations, Agroindustrial Residue

\title{
1. Introduction
}

In recent years worldwide, it has increased the demand for "green" fuel (biofuels) as an alternative to fossil fuels [1]. Biofuels are obtained from different crops such as sugarcane, eucalyptus, corn, soybean, poplar etc. [2]. Sugarcane as a biofuel crop has expanded in the last decade and today is ethanol obtained from sugarcane unites biofuel more employees [3]. Brazil's increased production, turning into the largest producer of sugarcane in the world, devotes roughly 50\% ethanol [4]. This crop has received much attention as one of the most socioeconomically important. Sugarcane/ethanol industry results in lots of waste as the vinasse. For each liter of ethanol, 10 to 15 liters of sugarcane vinasse are produced [5] [6]. Vinasse is the final by-product of the biomass distillation, mainly of the sugar-ethanol industry. This is dark brown slurry, unpleasant odor, acidic $\mathrm{pH}$ and a high organic content [7]. Because of its high pollution potential and the large quantities produced, alternatives for its use have been studied. Among them, it includes the use as a fertilizer in fertigation of the own sugarcane culture, by the application of raw vinasse in the soil, sometimes indiscriminately, causing major problems. Studies have shown that the vinasse application in soil may cause unbalance of nutrients, leaching of metals, salinization etc. [8].

The soil is an essential component of ecosystems and is the main substrate used by plants, playing multiple roles, such as regulation of the distribution, drainage, and infiltration of rainfall and irrigation [9]. Despite its importance, only few recent studies have focused on soil contamination compared those on water and air. For studies of soil contamination, higher plants are used worldwide, considered more sensitive and simpler than those using animals. According to Ma et al. (1995) [10], plants as direct receptors of pollutants, provide an important tool for genetic tests and environmental monitoring. They are considered excellent genetic models for detecting environmental mutagens [11] [12].

A. серa is one of the best test-systems already developed, due to its high sensitivity to chemical agents and good correlation with mammal test-systems [13] [14]. The sensitivity of tests with $A$. cepa has been reported as superior in $82 \%$ of the results obtained with rodents [15]. Tests with A. cepa have received special attention, maily after being adapted to evaluate the effects of pollutants in the soil and water, such as metals [16], chemical compounds from industrial effluents [17] and pesticides [18] [19].

In this context, in order to obtain more information about the possible effects of sugarcane vinasse on plants, the present study evaluated the toxic, cytotoxic and genotoxic potential of the raw sugarcane vinasse and diluted added to the soil, of two different harvests (Samples I and II), using the A. cepa test.

\section{Material and Methods}

\subsection{Tested Substance-Sugarcane Vinasse}

Vinasse samples (I and II) were collected at a sugarcane processing facility, located in São Paulo State, Brazil $\left(22^{\circ} 21^{\prime} 25^{\prime \prime} \mathrm{S} / 47^{\circ} 23^{\prime} 03^{\prime \prime} \mathrm{W}\right)$. The samples were maintained in a cold storage chamber $\left(4^{\circ} \mathrm{C}\right)$, at the Department of Biochemistry and Microbiology of the UNESP (São Paulo State University), Rio Claro, São Paulo, to minimize bacterial degradation until beginning of experiments.

\subsection{Test-Organism}

The biological material used on the evaluation of sugarcane vinasse toxicity was the seeds of $A$. cepa (Liliaceae), from the same lot and variety (Baia Periforme). They were stored in the dark at a temperature between $6{ }^{\circ} \mathrm{C}$ and $10{ }^{\circ} \mathrm{C}$ until use. 


\subsection{Control Substrate}

The soil used for the application of sugarcane vinasse samples, termed control soil (CS), was obtained on the

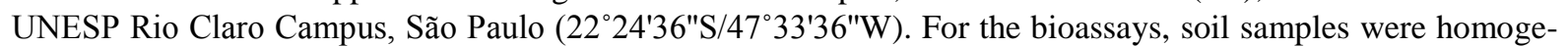
nized, dried at ambient temperature and sieved with 4-mm mesh sieves and subjected to chemical characterization.

\subsection{Chemical and Physico-Chemical Analysis}

Physicochemical analysis of the control soil (CS), raw sugarcane vinasse (RV), metals analysis of sugarcane vinasse samples and polycyclic hydrocarbons in control soil and the combinations of control soil and sugarcane vinasse samples, it was performed for guidelines of soil quality (mg/Kg) and groundwater quality in São Paulo State, according to the current legislation-CETESB 195/2005-E-to Environmental Sanitation Technology Company (Companhia de Tecnologia de Saneamento Ambiental-CETESB). For the CS samples, 16 priority aromatic polycyclic hydrocarbons established by the Environmental Protection Agency (EPA) were quantified following EPA 8270D method.

The maximum dosage of vinasse used was determined according to the current legislation P4.231 of the CETESB (2005).

\subsection{Treatment Groups}

Treatments were prepared with two different samples (I and II) of sugarcane vinasse, different controls (CS, NC and PC) and all bioassays were conducted in duplicate.

Groups 1: Negative control (NC)-ultrapure water.

Groups 2: Control soil (CS).

Groups 3: Raw vinasse (Samples I and II) (RV).

Groups 4: Raw vinasse (Samples I and II) + control soil (SV).

Groups 5: Vinasse (Samples I and II) diluted in water at 50\% + control soil (V 50\%).

Groups 6: Vinasse (Samples I and II) diluted in water at 25\% + control soil (V 25\%).

Groups 7: Vinasse (Samples I and II) diluted in water at $12.5 \%+$ control soil (V 12.5\%).

Groups 8: Positive control (PC), aneugenic herbicide Trifluralin® (TRIF) (CAS N01582-09-8) at a concentration of $0.019 \mathrm{mg} / \mathrm{mL}[18]$.

\subsection{Allium cepa Assay}

To evaluate the toxic, cytotoxic and genotoxic potential of the different groups, $A$. cepa seeds were used according to a modified version of Grant's protocol (1982) [13]. All treated groups with the different concentrations and samples (I and II) of sugarcane vinasse (RV, SV, V 50\%, V 25\% and V 12.5\%), were placed in Petri dishes with 100 seeds each. As well as, the negatives controls groups (NC and CS) and positive control groups (TRIF). The germination of all treatments was monitored between 4 to 5 days at $22^{\circ} \mathrm{C}$, until root tips reached 1.5 cm in length. Root tips were collected and fixed in Carnoy's solution (3:1 ethanol/glacial acetic acid v:v) and stored at $4{ }^{\circ} \mathrm{C}$ until use. For slide preparation, roots were prepared with the Feulgen reaction [20], followed by three baths with distilled water to remove the fixative excess. After the baths, roots were hydrolyzed with $\mathrm{HCl} 1$ $\mathrm{N}$ for 8 minutes at $60^{\circ} \mathrm{C}$, and later rinsed with distilled water and stained with Schiff reagent in the dark for $2 \mathrm{~h}$. The root meristems and the $F_{1}$ region were sectioned in a drop of acetic carmin (2\%), coversliped and gently pressed with the aid of a metal knife. Coverslips were removed with liquid nitrogen and after drying, slides were mounted with syntetic resin for later examination under light microscope. On each slide, 1000 meristem and $\mathrm{F}_{1}$ cells of A. cepa were examined (totalling approximately 5000 cells per treatment) under a light microscope.

\subsection{Toxic, Cytotoxic and Genotoxic Effects on Meristematic Cells of $A$. cepa}

The toxicity was evaluated based on the seed germination index, obtained by the ratio between the germinated seeds number and all the seeds exposed to germination.

Cytotoxicity was assessed based on the quantification of morphological cell alterations indicating cell death and on the mitotic index (MI), characterized by the total number of dividing cells in the cell cycle following the equation: $\mathrm{MI}=$ (number of dividing cells/total number of observed cells $) \times 100$. 
In the evaluation of the genotoxicity, cells with chromosome alterations were quantified and it was calculated of chromosomal aberration index (CAI) by the formula CAI = (number of cells with CA/total number of observed cells) $\times 100$.

\subsection{Micronuclei in Meristematic and $\mathrm{F}_{1}$ Region Cells of $A_{\text {. cepa }}$}

The micronuclei (MN) were counted in meristematic region cells and for the $\mathrm{F}_{1}$ region cells. The observation of $\mathrm{MN}$ in the $\mathrm{F}_{1}$ region cells permits examine possible damage fixation.

\subsection{Statistic Analysis}

The mean and standard deviation was calculated from the mitotic, chromosomal aberrations index and MN in meristematic and the $F_{1}$ region cells. The data do not follow a normal distribution (Shapiro-Wilk) and KruskalWallis test show differences between groups. All groups were compared to the NC by the non-parametric MannWhitney test, with the program Statistical Package for the Social Sciences for Windows, version 15.0, (SPSS Inc., Chicago, IL, EUA).

\section{Results}

\subsection{Fertility Analysis of the Control Substrate}

To ensure the correct application of sugarcane vinasse, similar to that applied in the field, the following parameters of fertility and the agronomic potential of the control soil (CS) were measured: $\mathrm{pH}$, organic matter (OM), residual phosphorus (P res), potassium (K), calcium (Ca), magnesium (Mg), exchangeable aluminum $(\mathrm{H}+\mathrm{Al})$, sum of bases (SB), cation exchange capacity (CTC), base saturation (V\%) and $\mathrm{Ca} / \mathrm{Mg}$ and $\mathrm{Mg} / \mathrm{K}$ ratios (Table 1). The control soil was classified as clay, slightly acidic, with low levels of organic matter and heavy metals.

\subsection{Chemical Characterization of Raw Sugarcane Vinasse Samples}

The results of the physicochemical analyses of the control soil and sugarcane vinasse samples are presented in Table 2. The $\mathrm{pH}$ of sugarcane vinasse was low in both samples, while biochemical oxygen demand (BOD), chemical oxygen demand (COD) and potassium levels were high.

Metal analyses of the control soil and sugarcane vinasse samples are presented in Table 3. Arsenic and copper concentrations in the control soil are above the reference levels for soil quality established by CETESB (195/2005-E), but below the limits for intervention in agricultural areas, which are $35 \mathrm{mg} / \mathrm{Kg}$ for arsenic and 200 $\mathrm{mg} / \mathrm{Kg}$ for copper. The concentrations of barium, copper, chrome, mercury, molybdenum, nickel and zinc were below the maximum concentration allowed (MCA).

\subsection{Characterization of Organic Compounds in Soil Samples}

None of the 16 priority aromatic polycyclic hydrocarbons (APHs) determined by the Environmental Protection Agency (EPA) was found in the study samples, as shown in Table 4 for both samples.

\subsection{Allium cepa Assay}

The results from the A. cepa assay, in which the cells were exposed to sugarcane vinasse samples and the negative and positive controls, are shown below in Table 5 (Sample I) and Table 6 (Sample II).

Table 1. Data on the control soil fertility.

\begin{tabular}{|c|c|c|c|c|c|c|c|c|c|c|c|c|}
\hline \multirow{2}{*}{ Samples } & \multirow{2}{*}{$\begin{array}{c}\mathrm{pH} \\
\mathrm{Ca} / \mathrm{Cl}_{2}\end{array}$} & \multirow{2}{*}{$\frac{\mathrm{g} / \mathrm{dm}^{3}}{\mathrm{OM}}$} & \multirow{2}{*}{$\begin{array}{c}\mathrm{mg} / \mathrm{dm}^{3} \\
\text { P res }\end{array}$} & \multicolumn{6}{|c|}{$\mathrm{mmol} / \mathrm{dm}^{3} \mathrm{TFSA}$} & \multirow{2}{*}{$\begin{array}{l}\% \\
\mathrm{~V}\end{array}$} & \multicolumn{2}{|c|}{ Ratios } \\
\hline & & & & $\mathrm{K}$ & $\mathrm{Ca}$ & $\mathrm{Mg}$ & $\mathrm{H}+\mathrm{Al}$ & SB & CTC & & $\mathrm{Ca} / \mathrm{Mg}$ & $\mathrm{Mg} / \mathrm{K}$ \\
\hline Crop I & 6.2 & 18 & 3 & 0.8 & 2 & 1 & 88 & 3.9 & 91.9 & 4.2 & 2 & 1.25 \\
\hline Crop II & 5.1 & 17 & 3 & 1.7 & 9 & 6 & 30 & 16.6 & 47.1 & 3.5 & - & - \\
\hline
\end{tabular}

TFSA: dried soil air; OM: organic matter; P res: residual phosphorus; SB: sum of bases; CTC: cation exchange capacity; V: base saturation. 
Table 2. Physicochemical analysis of the control soil and raw sugarcane vinasse samples.

\begin{tabular}{|c|c|c|c|c|c|}
\hline \multirow{2}{*}{ Parameters } & \multicolumn{2}{|c|}{ Sample I } & \multicolumn{2}{|c|}{ Sample II } & \multirow[b]{2}{*}{ Method } \\
\hline & CS (mg/Kg) & $\mathrm{RV}(\mathrm{mg} / \mathrm{Kg})(\mathrm{V})$ & CS (mg/Kg) & $\mathrm{RV}(\mathrm{mg} / \mathrm{Kg})(\mathrm{V})$ & \\
\hline Ammonia (mg/L) & & $<Q L$ & & $<\mathrm{QL}$ & USEPA 440/5-85-001 \\
\hline Calcium (mg/L) & 29.3 & 719 & 42.8 & 671 & SM21 3120 B \\
\hline $\mathrm{COD}(\mathrm{mg} / \mathrm{L})$ & & 5046 & & 7941 & SM21 5210 B \\
\hline BOD (mg/L) & & 13380 & & 25225 & SM21 5220 D \\
\hline Hardness (mg $\left.\mathrm{CaCO}_{3} / \mathrm{L}\right)$ & & 2493 & & 276 & SM21 2340 B \\
\hline Total phosphate (mg/L) & 317 & 1.3 & & $\mathrm{NE}$ & SM21 4500-P C \\
\hline Potassium (mg/L) & 437 & 2056 & $<0.008$ & 3401 & SM21 3120 B \\
\hline Non-filtrable residue (mg/L) & & 2765 & & 1800 & SM21 $3120 \mathrm{D}$ \\
\hline Sodium (mg/L) & $<\mathrm{QL}$ & 50.2 & & 114 & SM21 3120 B \\
\hline Sulfate (mg/L) & & 710 & $<0.5$ & 2993 & $\mathrm{SM} 214500-\mathrm{SO}_{4}^{2-} \mathrm{E}$ \\
\hline Organic Carbon & 12.6 & & 32.3 & & SSSA Cap40 \\
\hline Electric Conductivity ( $\mu \mathrm{s} / \mathrm{cm})$ & 115 & 13530 & 97.9 & 15110 & SM21 3120B \\
\hline Total Sulfur & 151 & 1219 & 123 & 1681 & SM21 3120B \\
\hline Total Phosphorus & 182 & & 317 & 207 & SM21 3120B \\
\hline Total Magnesium & $<\mathrm{QL}$ & 237 & $<\mathrm{QL}$ & 264 & SM21 3120B \\
\hline Nitrate (mg/Kg) & 4.4 & 1.3 & 8.14 & 1.49 & $\mathrm{SM} 214500-\mathrm{NO}_{3}^{-} \mathrm{E}$ \\
\hline Nitrite (mg/Kg) & 0.06 & 0.008 & 0.043 & 0.03 & SM21 4500- $\mathrm{NO}_{2}^{-} \mathrm{B}$ \\
\hline Amoniacal Nitrogen (mg/Kg) & 31.8 & & 49.6 & & SM21 $4500 \mathrm{NH}_{3} \mathrm{E}$ \\
\hline Nitrogen Kjeldal (mg/Kg) & 476 & 276 & 922 & 171 & SM21 4500-Norg B \\
\hline Nitrate (mg/Kg) & 4.4 & 1.3 & 8.14 & 1.49 & $\mathrm{SM} 214500-\mathrm{NO}_{3}^{-} \mathrm{E}$ \\
\hline Nitrite (mg/Kg) & 0.06 & 0.008 & 0.043 & 0.03 & SM21 4500- $\mathrm{NO}_{2}^{-} \mathrm{B}$ \\
\hline $\mathrm{pH}$ & 6.2 & 3.9 & 5.1 & 4.37 & EPA 4095 C \\
\hline Total Potassium & 406 & 2056 & $<\mathrm{QL}$ & 3401 & SM21 3120B \\
\hline Total Sodium & $<\mathrm{QL}$ & 50.2 & $<\mathrm{LQ}$ & 114 & SM21 2540B \\
\hline Total Solids & 0.86 & & 0.93 & & SM21 2540B \\
\hline Total Volatile Solids & IV & & 0.08 & & SM21 2540B \\
\hline Solid content & 0.86 & & 0.93 & & SM21 2540B \\
\hline Moisture (g/g) & 0.14 & & 0.06 & & SM21 2540B \\
\hline
\end{tabular}

CS: control soil; RV: raw vinasse; IV: inconsistent value; NE: data not evaluated; QL: quantification limit; SM: standard methods of the water and wastewater; RV: guidelines of soil quality $(\mathrm{mg} / \mathrm{Kg})$ and groundwater quality in São Paulo State, according to CETESB (195/2005-E); EPA: Environmental Protection Agency, US.

Table 3. Metals analysis of the control soil and raw sugarcane vinasse samples.

\begin{tabular}{cccccccc}
\hline & \multicolumn{3}{c}{ Sample I } & \multicolumn{3}{c}{ Sample II } \\
\cline { 2 - 7 } Parameters & $\mathrm{CS}(\mathrm{mg} / \mathrm{Kg})$ & $\mathrm{RV}(\mathrm{mg} / \mathrm{Kg})(\mathrm{V})$ & $\mathrm{CS}(\mathrm{mg} / \mathrm{Kg})$ & $\mathrm{RV}(\mathrm{mg} / \mathrm{Kg})(\mathrm{V})$ & Method & $\mathrm{VR}(\mathrm{mg} / \mathrm{Kg})$ \\
\hline \multirow{2}{*}{ Arsenic } & 16.8 & & $<\mathrm{QL}$ & $<\mathrm{QL}$ & $\mathrm{SM} 213120 \mathrm{~B}$ & 3.5 \\
Barium & 5.91 & 0.41 & $<\mathrm{QL}$ & $<\mathrm{QL}$ & $\mathrm{SM} 213120 \mathrm{~B}$ & 75 \\
\hline
\end{tabular}




\section{Continued}

\begin{tabular}{|c|c|c|c|c|c|c|}
\hline Cadmium & $<\mathrm{QL}$ & $<\mathrm{LQ}$ & $<0.16$ & $<\mathrm{QL}$ & SM21 3120B & $<0.5$ \\
\hline Lead & 49.3 & $<\mathrm{QL}$ & 42.7 & $<\mathrm{QL}$ & SM21 3120B & 17 \\
\hline Copper & 37.2 & 0.35 & 76.5 & 0.76 & SM21 3120B & 35 \\
\hline Chromium & 31.2 & 0.04 & 108 & 3.56 & SM21 3120B & 40 \\
\hline Total Sulfur & 151 & 1219 & 123 & 1681 & SM21 3120B & \\
\hline Mercury & $<\mathrm{QL}$ & 0.0019 & 0.065 & $<\mathrm{QL}$ & EPA 470A & 0.05 \\
\hline Molybdenum & 3.64 & 0.008 & 9.6 & $<\mathrm{QL}$ & SM21 3120B & $<4$ \\
\hline Nickel & 13 & 0.03 & 24.2 & $<\mathrm{QL}$ & SM21 3120B & 13 \\
\hline Selenium & $<\mathrm{QL}$ & $<\mathrm{QL}$ & 52.1 & $<\mathrm{QL}$ & SM21 3120B & 0.25 \\
\hline Total Sodium & $<\mathrm{QL}$ & 50.2 & $<\mathrm{LQ}$ & 114 & SM21 2540B & \\
\hline Zinc & 23.2 & 1.66 & 96 & $<\mathrm{QL}$ & SM21 3120B & 60 \\
\hline
\end{tabular}

CS: control soil; RV: raw vinasse; SM: standard methods of the water and wastewater; EPA: Environmental Protection Agency, US; QL: quantification limit; RV: guidelines of soil quality (mg/Kg) and groundwater quality in São Paulo State, according to CETESB (195/2005-E)

Table 4. Analysis of aromatic polycyclic hydrocarbons in the samples of control soil and the combinations of control soil + vinasse.

\begin{tabular}{|c|c|c|c|c|c|}
\hline \multirow{2}{*}{ Parameters } & \multicolumn{2}{|c|}{ Sample } & \multirow{2}{*}{ Method } & \multicolumn{2}{|c|}{ Concentration allowed in the soil (mg/Kg) } \\
\hline & CS & SV & & CB & $\mathrm{CO}$ \\
\hline Acenaphthene ( $\mu \mathrm{g} / \mathrm{Kg})$ & $<\mathrm{QL}$ & $<\mathrm{QL}$ & EPA $8270 \mathrm{D}$ & - & - \\
\hline Acenaphthylene $(\mu \mathrm{g} / \mathrm{Kg})$ & $<\mathrm{QL}$ & $<\mathrm{QL}$ & EPA 8270 D & - & - \\
\hline Anthracene $(\mu \mathrm{g} / \mathrm{Kg})$ & $<\mathrm{QL}$ & $<\mathrm{QL}$ & EPA $8270 \mathrm{D}$ & - & - \\
\hline Benzo (a) anthracene ( $\mu \mathrm{g} / \mathrm{Kg})$ & $<\mathrm{QL}$ & $<\mathrm{QL}$ & EPA 8270 D & 0.025 & 0.025 \\
\hline Benzo (a) pyrene ( $\mu \mathrm{g} / \mathrm{Kg})$ & $<\mathrm{QL}$ & $<\mathrm{QL}$ & EPA $8270 \mathrm{D}$ & 0.052 & 0.052 \\
\hline Benzo (a) fluoranthene (mg/Kg) & $<\mathrm{QL}$ & $<\mathrm{QL}$ & EPA $8270 \mathrm{D}$ & 0.38 & - \\
\hline Benzo (a) perylene (mg/Kg) & $<\mathrm{QL}$ & $<\mathrm{QL}$ & EPA $8270 \mathrm{D}$ & 0.57 & \\
\hline Benzo (a) fluoanthene $(\mu \mathrm{g} / \mathrm{Kg})$ & $<\mathrm{QL}$ & $<\mathrm{QL}$ & EPA $8270 \mathrm{D}$ & 0.38 & 0.38 \\
\hline Chrysene (mg/Kg) & $<\mathrm{QL}$ & $<\mathrm{QL}$ & EPA $8270 \mathrm{D}$ & 8.1 & - \\
\hline Dibenzo (a,h) anthracene (mg/Kg) & $<\mathrm{QL}$ & $<\mathrm{QL}$ & EPA $8270 \mathrm{D}$ & 0.08 & - \\
\hline Phenanthrene $(\mu \mathrm{g} / \mathrm{Kg})$ & $<\mathrm{QL}$ & $<\mathrm{QL}$ & EPA $8270 \mathrm{D}$ & 3.3 & 3.3 \\
\hline Fluoranthene $(\mu \mathrm{g} / \mathrm{Kg})$ & $<\mathrm{QL}$ & $<\mathrm{QL}$ & EPA $8270 \mathrm{D}$ & - & - \\
\hline Fluorenone $(\mu \mathrm{g} / \mathrm{kg})$ & $<\mathrm{QL}$ & $<\mathrm{QL}$ & EPA $8270 \mathrm{D}$ & - & - \\
\hline Indeno (1,2,3-cd) pyrene ( $\mu \mathrm{g} / \mathrm{Kg})$ & $<\mathrm{QL}$ & $<\mathrm{QL}$ & EPA 8270 D & 0.031 & 0.031 \\
\hline Naphthalene ( $\mu \mathrm{g} / \mathrm{Kg})$ & $<\mathrm{QL}$ & $<\mathrm{QL}$ & EPA $8270 \mathrm{D}$ & 0.12 & 0.12 \\
\hline Pyrene $(\mu \mathrm{g} / \mathrm{Kg})$ & $<\mathrm{QL}$ & $<\mathrm{QL}$ & EPA 8270 D & - & - \\
\hline
\end{tabular}

CS: control soil; SV: control soil + vinasse CB: guidelines (prevention) for soils in São Paulo State according to CETESB 9195/2005-E); CO: maximum concentration allowed in the soil, according to CONAMA (375/2006); EPA: Environmental Protection Agency, US; QL: quantification limit. 
Table 5. Mean and standard deviation of the mitotic, chromosomal aberrations index in 5000 meristematic cells of $A$. cepa and $\mathrm{MN}$ in meristematic and the $\mathrm{F}_{1}$ region cells, after exposure to ultrapure water (negative control), trifluralin (positive control), control soil (CS), control soil + vinasse (Sample I) and three concentrations of vinasse (Sample I).

\begin{tabular}{ccccc}
\hline \multicolumn{4}{c}{ Parameters analysed/5000 cells } \\
\hline Groups & MI & CAI & MN $(\mathrm{M})$ & MN $\left(\mathrm{F}_{1}\right)$ \\
\hline NC & $29.1 \pm 3.7$ & $0.2 \pm 0.2$ & $0.2 \pm 0.4$ & $0.4 \pm 0.5$ \\
CS & $29.9 \pm 1.7$ & $0.4 \pm 0.2$ & $0.4 \pm 0.5$ & $0 \pm 0$ \\
SV & $29.4 \pm 2.6$ & $3.8 \pm 0.6^{*}$ & $1.2 \pm 0.4^{*}$ & $0.4 \pm 0.5$ \\
V (50\%) & $41.7 \pm 13.4$ & $1.4 \pm 0.6^{*}$ & $0.4 \pm 0.5$ & $2.2 \pm 1.5$ \\
V (25\%) & $34.5 \pm 3.3$ & $1.6 \pm 0.7^{*}$ & $0.6 \pm 0.9$ & $0.8 \pm 0.8$ \\
V (12.5\%) & $42.4 \pm 10.5$ & $1.3 \pm 0.4^{*}$ & $0.6 \pm 0.5$ & $1 \pm 1$ \\
TRIF & $19.4 \pm 1.4^{*}$ & $10.2 \pm 1.6^{*}$ & $10.4 \pm 1.3^{*}$ & $2.6 \pm 1.1^{*}$ \\
\hline
\end{tabular}

NC: negative control; TRIF: trifluralin-positive control; CS: control soil; SV: control soil + vinasse (Sample I); V: vinasse (Sample I); MI: mitotic index; CAI: chromosomal aberration index; $\mathrm{MN}(\mathrm{M})$ : micronuclei in meristematic cells; $\mathrm{MN}\left(\mathrm{F}_{1}\right)$ : micronuclei in cells of the region $\mathrm{F}_{1}$. ${ }^{*} p<0.05$. Values statistically significant, compared to negative control with the Mann Whitney test.

Table 6. Mean and standard deviation of the mitotic, chromosomal aberrations index in 5000 meristematic cells of $A$. cepa and $\mathrm{MN}$ in meristematic and the $\mathrm{F}_{1}$ region cells, after exposure to ultrapure water (negative control), trifluralin (positive control), control soil (CS), control soil + vinasse (Sample II) and three concentrations of vinasse (Sample II).

\begin{tabular}{ccccc}
\hline & \multicolumn{3}{c}{ Parameters analysed/5000 cells } \\
\hline Groups & MI & CAI & MN (M) & MN $\left(\mathrm{F}_{1}\right)$ \\
\hline NC & $50.4 \pm 7.7$ & $0.3 \pm 0.2$ & $0.4 \pm 0.5$ & $0.2 \pm 0.4$ \\
CS & $57.2 \pm 13.5$ & $0.5 \pm 0.5$ & $0.8 \pm 0.8$ & $0 \pm 0$ \\
SV & $64.0 \pm 7.9^{*}$ & $1.3 \pm 0.6^{*}$ & $2.8 \pm 1.5^{*}$ & $1.0 \pm 0.7$ \\
V (50\%) & $63.2 \pm 9.8^{*}$ & $2.6 \pm 1.1^{*}$ & $3.0 \pm 2.8^{*}$ & $1.0 \pm 1.0$ \\
V (25\%) & $55.2 \pm 7.9$ & $2.2 \pm 0.7^{*}$ & $2.6 \pm 0.5^{*}$ & $0.2 \pm 0.4$ \\
V (12.5\%) & $61.7 \pm 3.7$ & $3.7 \pm 1.4^{*}$ & $1.8 \pm 0.8^{*}$ & $2.2 \pm 3.3$ \\
TRIF & $37.8 \pm 9.6$ & $9.1 \pm 3.3^{*}$ & $19.8 \pm 13.1^{*}$ & $3.6 \pm 1.8^{*}$ \\
\hline
\end{tabular}

NC: negative control; TRIF: trifluralin-positive control; CS: control soil; SV: control soil + vinasse (Sample II); V: vinasse (Sample II); MI: mitotic index; CAI: chromosomal aberration index; $\mathrm{MN}(\mathrm{M})$ : micronuclei in meristematic cells; $\mathrm{MN}\left(\mathrm{F}_{1}\right)$ : micronuclei in cells of the region $\mathrm{F}_{1} .^{*} p<0.05$. Values statistically significant, compared to negative control with the Mann Whitney test.

The germination in the treated groups (V 50\%, V 25\% and V 12.5\%) and control groups (CS and NC) was over $90 \%$. In the RV seeds did not germinate and in SV, the germination index was below $5 \%$.

The MI was analyzed, which represented the number of dividing cells. In the Sample I, no significant differences and in the Sample II, the groups SV and V 50\% showed significant differences were observed when comparing the treatments with the negatives controls $(p<0.05)$.

The genotoxic potential was evaluated by the CAI for all treatments (SV, V 50\%, V 25\% and V 12.5\%) and was statistically significant when comparing with the negatives controls $(p<0.05)$. The CAs and nuclear abnormalities observed in the present study were visualized at all stages of the cell cycle. Several types of aberrations were considered [14]. The most frequent aberrations were metaphase with chromosome adherence, anaphase with chromosome loss and polyploid anaphase.

It was also quantified the presence of $\mathrm{MN}$ in meristematic and $\mathrm{F}_{1}$ region cells (Table 5 and Table 6). The MN in meristematic cells was only statistically significant for treatments SV in Sample I, but in Sample II, all treatments were statistically significant when comparing with the negatives controls $(p<0.05)$. No differences statistically significant were observed comparing with the negatives controls $(p<0.05)$ for MN in $\mathrm{F}_{1}$ region cells, in any of the samples evaluated. 


\section{Discussion}

Several alternatives have been developed for the use of vinasse from sugarcane in Brazil, in order to the large volumes that are produced daily. Therefore, every day becomes more necessary the assessments of possible damage to exposed ecosystems. Therefore, this study intended to contribute to a better understanding of the toxicity that this residue derived from the ethanol industry can have on soil.

Thus, the initial chemical analysis of the soil is of great importance to identify and quantify the different chemical elements present in the soil samples used in this study. Also is very important to determine the chemical and physico-chemical characteristics of the vinasse sample study which vary depending on the harvest. This analysis allowed to reproducing the correct amount of application of vinasse in soils on the recommendation of the legislation (CETESB P4.231/2005).

The addition of sugarcane vinasse on the soil can bring harmful effects in the terrestrial ecosystems, for example in the seed germination and alterations in the genetic material of exposed organisms [6]. In the present study, the RV seeds did not germinate indicating that vinasse has a toxic potential for A. cepa seeds, probably due to the low pH. From an ecological perspective, it is important to take into account the pH of the substrate where seeds will germinate and grow, due to its direct effect on plants, in addition to nutrient release [21]. This result can also be due to the large quantity of potassium present in the vinasse samples, as hydric and saline stresses are correlated with the excess of soluble salts, reducing the potential of water in the soil and consequently, preventing the absorption of water by seeds in general [22]. According to Leonel and Rodrigues (1999) [23], when the levels of potassium nitrate were tested in citrus seeds, the results showed a toxic potential, inhibiting their germination. Studies conducted by Gazziero et al. (1991) [24] also showed that potassium nitrate did not promote the germination of Sorghum halepense seeds.

This study did not reveal a significant reduction in the MI at the evaluated vinasse samples, being this a parameter that allows for the estimation of the frequency of cellular division, used for identify the presence of cytotoxic pollutants in the environment [25]. The examination of meristematic cells exposed to different samples, revealed increase in the frequency of CAs in the $A$. cepa cells.

Chromosome loss and polyploidy are events that can derive from problems in cytoplasmic microtubules [18]. Metaphases with chromosome adherence indicate a toxic effect on chromosomes, characterizing an irreversible effect on the cell [26]. According to Liu et al. (1994) [27], chromosome adherence might be due to the presence of cadmium in some compounds that can cause cell alterations even in small quantities. Also according to [28], adherence is a commom sign of toxic effects on the genetic material and may cause irreversible effects on the cell. One of the consequences of adherence may be the chromosomal loss [29]. In this case, chromosomes keeps united and when they separate may be broken and/or lost [30]. This phenomenon can lead to cases of aneuploidy and polyploidy [31]-[33].

Polyploid cells have a large chromosomal imbalance due to the diversion of chromosomal number. In this case, the chromosomes tend to be condensed [31] [34] promoting the adhesion of chromosomes and chromatids [18].

A substance capable of inducing the formation of micronucleus may be considered a clastogenic or aneugenic compound. The claustogenic action of a substance is demonstrated by the presence of micronuclei from chromosome breaks during the process of cell division. The aneugenic action, on the other hand, is characterized by the inactivation of the mitotic fuse, which results in loss of entire chromosomes that become absent in the main nucleus of the cell [35].

Genotoxicity studies are very important and have been several reports of damage to the genetic material from different organisms exposed to vinasse for example in Drosophila melanogaster [36], Tradescantia pallida [37] and Saccharum species hybrids [38]. According to the latter authors, these alterations were caused by the high concentrations of $\mathrm{K}, \mathrm{P}, \mathrm{S}, \mathrm{Fe}, \mathrm{Mn}, \mathrm{Zn}$ and $\mathrm{Cu}$ and heavy metals such as $\mathrm{Cd}, \mathrm{Cr}, \mathrm{Ni}$ and $\mathrm{Pb}$.

Souza et al. (2009) [39] in a study on the clastogenic/aneugenic potential of land farming soil from a petroleum refinery before and after addition of sugarcane vinasse reported a significant increase in chromosome aberrations in $A$. cepa seeds as chromosome breakages. This clastogenic effect is probably due to release of metal contained in land farming caused by sugarcane vinasse.

In the other hand, Christofoletti et al. (2013) [17] evaluated the toxic potential of biosolid, sugarcane vinasse and a combination of both residues using A. сера assay. The authors also observed sugarcane vinasse genotoxicity for chromosome aberrations as for example, cells in metaphase with chromosome adherence, polyploid 
metaphases and anaphases, anaphase with chromosome bridges and with chromosome loss and cells with nuclear buds.

Based on the results obtained, this evaluation indicates the importance of studies to assess the toxic, cytotoxic and genotoxic potential of different residues disposed in the environment. These residues may induce alterations that cause irreversible damage to organisms and ecosystems.

\section{Conclusion}

After the quantification of the seeds germination and chromosomal aberrations in the test system here applied, it was concluded that the sugarcane vinasse in natura and in different dilutions showed a toxic and genotoxic potential for the A. cepa species. Maybe the low $\mathrm{pH}$, electric conductivity, and chemical elements present in sugarcane vinasse may cause changes in the chemical and physical-chemical properties of soils. Results of this study reinforce the need for more research to evaluate the biological effects of sugarcane vinasse discharged into the environment in different ecosystems compartments, as well as different levels of biological organization.

\section{Acknowledgements}

The authors thank the Fundação de Amparo à Pesquisa do Estado de São Paulo (FAPESP), processes 2009/ 53047-9, 2009/50578-3 and 2012/50197-2), for financial support and Thays Casimiro Fernandes for suggestions.

\section{References}

[1] Tsao, C.C., Campbell, J.E., Mena-Carrasco, M., Spak, S.N., Carmichael, G.R. and Chen, Y. (2012) Increased Estimates of Air-Pollution Emissions from Brazilian Sugar-Cane Ethanol. Nature Climate Change, 2, 53-57. http://dx.doi.org/10.1038/nclimate1471

[2] Smeets, E.M.W., Faaij, A.P.C., Lewandowski, I.M. and Turkenburg, W.C. (2007) A Bottom-Up Assessment and Review of Global Bio-Energy Potentials to 2050. Progress in Energy and Combustion Science, 33, 56-106. http://dx.doi.org/10.1016/j.pecs.2006.08.001

[3] Gunkel, G., Kosmol, J., Sobral, M., Rohn, H., Montenegro, S. and Aureliano, J. (2007) Sugar Cane Industry as a Source of Water Pollution Case Study on the Situation in Ipojuca River Pernambuco Brazil. Water, Air, and Soil Pollution, 180, 261-269. http://dx.doi.org/10.1007/s11270-006-9268-x

[4] Rudorff, B.F.T., Aguiar, D.A., Silva, W.F., Sugawara, L.M., Adami, M. and Moreira, M.A. (2010) Studies on the Rapid Expansion of Sugarcane for Ethanol Production in Sao Paulo State (Brazil) Using Landsat Data. Remote Sensing, 2, 1057-1076. http://dx.doi.org/10.3390/rs2041057

[5] Cortez, L., Magalhães, P. and Happi, J. (1992) Principais subprodutos da agroindústria canavieira e sua valorização. Revista brasileira de energia elétrica, 2, 111-146.

[6] Christofoletti, C.A., Pedro Escher, J., Correia, J.E., Urbano Marinho, J.F. and Fontanetti, C.S. (2013) Sugarcane Vinasse: Environmental Implications of Its Use. Waste Management, 33, 2752-2761. http://dx.doi.org/10.1016/j.wasman.2013.09.005

[7] España-Gamboa, E., Mijangos-Cortes, J., Barahona-Perez, L., Dominguez-Maldonado, J., Hernández-Zarate, G. and Alzate-Gaviria, L. (2011) Vinasse: Characterization and Treatments. Waste Manage, 29, 1235-1250. http://dx.doi.org/10.1177/0734242X10387313

[8] Santana, V.S. and Machado, N.R.C.F. (2008) Photocatalytic Degradation of the Vinasse under Solar Radiation. Catalysis Today, 133, 606-610. http://dx.doi.org/10.1016/j.cattod.2007.12.131

[9] Kataoka, A.P.A.G. (2001) Biodegradação de resíduo oleoso de refinaria de petróleo por microrganismos isolados de "landfarming”. PhD Thesis, Bioscience Institute, Unesp-Rio Claro.

[10] Ma, T.H., Xu, Z., Xu, C., Mc Connell, H., Rabago, E.V., Areola, G.A. and Zhang, H. (1995) The Improved Allium/ Vicia Root Tip Micronucleus Assay for Clastogenicity of Environmental Pollutants. Mutation Research, 334, 185-195. http://dx.doi.org/10.1016/0165-1161(95)90010-1

[11] Andrioli, N.B., Soloneski, S., Larramendy, M.L. and Mudry, M.D. (2012) Cytogenetic and Microtubule Array Effects of the Zineb-Containing Commercial Fungicide Formulation Azzurro ${ }^{\circledR}$ on Meristematic Root Cells of Allium cepa L. Mutation Research, 742, 48-53. http://dx.doi.org/10.1016/j.mrgentox.2011.11.014

[12] Herrero, O., Perez-Martin, J.M., Fernandez, P., Carvajal, L., Peropadre, A. and Hazen, M.J. (2012) Toxicological Evaluation of Three Contaminants of Emerging Concern by Use of the Allium cepa Test. Mutation Research, 743, 20-24. http://dx.doi.org/10.1016/j.mrgentox.2011.12.028 
[13] Grant, W.F. (1982) Chromosome Aberration Assays in Allium. A Report of the U.S. Environmental Protection Agency Gene-Tox Program. Mutation Research, 99, 273-291. http://dx.doi.org/10.1016/0165-1110(82)90046-X

[14] Leme, M.D. and Marin-Morales, M.A. (2009) Allium cepa Test in Environmental Monitoring: A Review on Its Application. Mutation Research, 10, 1016. http://dx.doi.org/10.1016/j.mrrev.2009.06.002

[15] Rank, J. and Nielsen, M.H. (1998) Genotoxicity Testing of Wastewater Sludge Using the A. cepa Anaphase-Telophase Chromosome Aberration Assy. Mutation Research, 4148, 113-119. http://dx.doi.org/10.1016/S1383-5718(98)00118-1

[16] Francisco, A., Christofoletti, C.A. and Fontanetti, C.S. (2014) Evaluation of Allowed Parameters for Nickel in Freshwater Bodies Using the Allium cepa Test. Semina. Ciências Biológicas e da Saúde (Online), 35, 49-60. http://dx.doi.org/10.5433/1679-0367.2014v35n1p49

[17] Christofoletti, C.A., Pedro-Escher, J. and Fontanetti, C.S. (2013) Assessment of the Genotoxicity of Two Agricultural Residues after Processing by Diplopods Using the Allium cepa Assay. Water Air Soil Pollution, 224, 1523. http://dx.doi.org/10.1007/s11270-013-1523-3

[18] Fernandes, T.C.C., Mazzeo, D.E.C. and Marin-Morales, M.A. (2007) Mechanism of Micronuclei Formation in Polyploidizated Cells of Allium cepa Exposed to Trifluralin Herbicide. Pesticide Biochemistry and Physiology, 88, 252-259. http://dx.doi.org/10.1016/j.pestbp.2006.12.003

[19] Rodríguez, Y.A, Christofoletti, C.A., Pedro-Ester, J., Correa, O.B., Malaspina, O., Costa Ferreira, R.F. and Fontanetti, C.S. (2015) Allium cepa and Tradescantia pallida Bioassays to Evaluate Effects of the Insecticide Imidacloprid. Chemosphere, 120, 438-442. http://dx.doi.org/10.1016/j.chemosphere.2014.08.022

[20] Mello, M.L.S. and Vidal, B.C. (1978) A reação de Feulgen. Ciência e Cultura, 30, 665-676.

[21] Perez, S.C.J.G.A. and Moraes, J.A.P.V. (1991) Curso diário e sazonal do potencial da água e da condutância estomática em espécies de cerradão. Revista Brasileira de Biologia, São Carlos, 51, 805-811.

[22] Cavalcante, A.M.B. and Perez, S.C.J.G. (1995) Efeitos dos estresses híbrido e salino sobre a germinação de Leucaena leucocephala (Lam.) de Wit. Pesquisa Agropecuária Brasileira, 3, 281-289.

[23] Leonel, S. and Rodrigues, J.D. (1999) Efeitos de giberelinas citocininas e do nitrato de potássio no proceso germinativo de sementes de limoeiro cravo (Citrus limonia Osbeck). Scientia Agricola, 56, 111-116. http://dx.doi.org/10.1590/S0103-90161999000100017

[24] Gazziero, D.P.L., Kzryzanowski, F.C., Ulbrich, A.V. and Pitelli, R.A. (1991) Estudo da superação da dormência de sementes de capim massambrá (Sorghim halepense-L. PERS) através de nitrato de potássio e ácido sulfúrico. Revista Brasileira de Sementes, 1, 21-24. http://dx.doi.org/10.17801/0101-3122/rbs.v13n1p21-24

[25] Fiskesjö, G. (1985) The Allium Test as a Standard in Environmental Monitoring. Hereditas, 102, 99-112. http://dx.doi.org/10.1111/j.1601-5223.1985.tb00471.x

[26] Marcano, L., Bracho, M., Montiel, X., Carruyo, I. and Atencio, L. (1998) Efecto mtotóxico y genotoxico del cadmio em problaciones meristemáticas de Allium cepa L. (cebolla). Ciência, 6, 93-99.

[27] Liu, D.H., Jiang, W.S., Wang, W., Zhao, F. and Lu, C. (1994) Effects of Lead on Root Growth, Cell Division, and Nucleolus of Allium cepa. Environmental Pollution, 86, 1-4. http://dx.doi.org/10.1016/0269-7491(94)90002-7

[28] Türkoglu, S. (2007) Genotoxicity of Five Food Preservatives Tested on Root Tips of Allium cepa L. Mutation Research, 71, 127-131. http://dx.doi.org/10.1016/j.mrgentox.2006.07.006

[29] Marcano, L., Carruyo, I., Del Campo, A. and Montiel, X. (2004) Cytotoxicity and Mode of Action of Maleic Hydrazide on Root Tips of Allium cepa L. Environmental Research, 94, 221-226. http://dx.doi.org/10.1016/S0013-9351(03)00121-X

[30] Marcano, L., Carruyo, I., Del Campo, A., Montiel, X. and Moreno, P. (1999) Inhibición de la actividad biossinética nucleolar inducidas por el plomo en meristemos radiculares de cebolla (Allium cepa). Revista de la Facultad de Agronomia de La Universidad del Zulia, 16, 476-487.

[31] FIskejö, G. (1988) The Allium Test-An Alternative in Environmental Studies-The Relative Toxicity of Metal-Ions. Mutation Research, 197, 243-260. http://dx.doi.org/10.1016/0027-5107(88)90096-6

[32] Matsumoto, S.T. and Marin-Morales, M.A. (2004) Mutagenic Potential Evaluation of the Water of a River That Receives Tannery Effluents Using the Allium cepa Test System. Cytologia, Tokyo, 69, 399-408. http://dx.doi.org/10.1508/cytologia.69.399

[33] Matsumoto, S.T., Mantovani, M.S., Malagutti, M.I.A., Dias, A.L., Fonseca, I.C. and Marin-Morales, M.A. (2006) Genotoxicity and Mutagenicity of Water Contaminated with Tannery Effluents, as Evaluated by the Micronucleus Test and Comet Assay Using the Fish Oreochromis niloticus and Chromosome Aberrations in Onion root-tips. Genetics Molecular Biology, 29, 148-158. http://dx.doi.org/10.1590/S1415-47572006000100028

[34] FIskejö, G. and Levan, A. (1993) Evaluation of the First Tem MeiC Chemicals in the Allium cepa. Atlas, 21, $139-149$.

[35] Fenech, M. (2000) The in Vitro Micronucleus Technique. Mutation Research, 455, 81-95. http://dx.doi.org/10.1016/S0027-5107(00)00065-8 
[36] Yesilada, E. (1999) Genotoxic Activity of Vinasse and Its Effect on Fecundity and Longevity of Drosophila melanogaster. Bulletin of Environmental Contamination and Toxicology, 63, 560-566. http://dx.doi.org/10.1007/s001289901017

[37] Pedro-Escher, J., Maziviero, G.T. and Fontanetti, C.S. (2014) Mutagenic Action of Sugarcane Vinasse in the Tradescantia pallida Test System. Journal of Ecosystem \& Ecography, 4, 145. http://dx.doi.org/10.4172/2157-7625.1000145

[38] Srivastava, S. and Jain, R. (2010) Effect of Distillery Spent Wash on Cytomorphological Behaviour of Sugarcane Settlings. Journal of Environmental Biology, 31, 809-812.

[39] Souza, T.S., Hencklein, F.A., Angelli, D.F., Gonçales, R.A. and Fontanetti, C.S. (2009) The Allium cepa Bioassay to Evaluate Landfarming Soil, before and after the Addiction of Rice Hulls to Accelerate Organic Pollutants Biodegradation. Ecotoxicology and Environmental Safety, 72, 1365-1368. 